\title{
Holdt tesen?
}

\section{Af Kaj Thaning}

I Grundtvig-studier 1965 havde jeg lejlighed til at svare de tre af mine kritikere, der havde ytret sig i årbogen, og som jeg i min bog havde taget stilling til. En langt mere væsentlig debat står dog tilbage, idet min førsteopponent Pontoppidan Thyssen i udvidet form har offentliggjort sin opposition i Kirkehistoriske samlinger bind V hefte 3 r965, suppleret med et resume af min bog, som jeg selv havde lejlighed til at gennemse og rette på punkter, hvor jeg ikke kunde godkende referatet eller savnede noget væsentligt - alt dog inden for de givne rammer. Mit eget tyske resume gik ikke i enkeltheder, men var et tværgående sammendrag til brug for udlændinge, der skulde have et indtryk af Grundtvig og bogens syn på ham.

Ganske naturligt, er P. Th. den, der har gjort langt det største arbejde med stoffet, og hans indvendinger er ynglet frem undervejs. Han har ikke kunnet godtage min tese om den afgørende betydning af året 1832 og vil istedet udjævne Grundtvigs udvikling ved at vise, dels at Grundtvig for det år var klar over ting, som jeg mener først gik op for ham i gennembrudsåret, dels ved at forlægge det væsentlige gennembrud til nogle år efter 1832 . Men iøvrigt vil han påpege fortløbende selvmodsigelser $\mathrm{i}$ hans syn. Derudover angriber han min tolkning som bestemt af moderne synspunkter. Der er både metodisk, eksegetisk og teologisk uenighed imellem os. Så der er nok at tage fat på. Hans anerkendelse af mit arbejde lader jeg ligge.

Beslægtet med P. Th.s kritik er Bugges indvendinger (disp. s. $255 \mathrm{f}$ ). Af pladsmæssige grunde er det mig umuligt her at svare på alt, så jeg vælger at udelade al kritik af min gennemgang af Grundt-

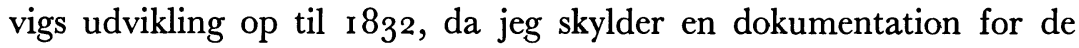
første 50 sider af min bog. 5 gange så meget stof blev tilbudt mine bedømmere, og det er endda kun halvdelen af, hvad jeg håber engang at kunne forelægge til underbygning af mit syn på Grundtvigs »kamp for klarhed « indtil afklaringen. Forhåbentlig vil det da kunne 
ses, at denne overskrift netop kan sættes over hele perioden indtil I832.

Når man imidlertid imod min tese anfører alt, hvad der er »foregrebet« før 1832 , kan jeg dog svare (som over for Bugge under disputatshandlingen i i 965 ), at jeg i hvert fald i3 gange selv har peget på linier, der førte frem til 1832 . P. Th. har hos mig forstået Grundtvigs bodskristelige anfægtelse alt for kvantitativt. Den er netop en anfægtelse mere end en ideologi og kommer langt stærkere frem end ellers i de perioder, hvor han var præst - og havde præsteedens forpligtelse hængende over hovedet.

De to kritikere har meget at sige om alt det i forfatterskabet, uden hvilket klarheden af $183_{2}$ ikke kunde tænkes - og det er heltud rigtigt, at alt er forudsætning for det, der siden sker. Uden forudsætninger intet problem - og ingen løsning af problemet. Spørgsmålet er blot, hvad der er det afgørende for problemets løsning, og hvori denne består. I og for sig er det jo rigtigt, når P. Th. hævder, at selv om der samtidigt sker en række afgørende ændringer i Grundtvigs syn på en række forskellige felter, følger ikke deraf, at de må føres tilbage til en fælles årsag (s. 567). Men det kan også være en pedantisk indvending. Jeg har imidlertid nok gjort den fejl, at jeg ikke har givet en kort fremstilling af den indre sammenhæng, hvad Grundtvigs »omvendelse til livet« angår. Det skyldes den illusion hos mig, at sammenhængen blev indlysende gennem den brede gennemgang af de forskellige samtidige ændringer. Men en dag vil forsømmelsen kunne indhentes.

Bugges disputats »Skolen for livet« støtter min opfattelse af afklaringen i $183_{2}$ - selvom han omhyggeligt søger at præcisere forskelle i opfattelsen. Tilmed dokumenterer han, at Grundtvigs hjem var præget af, hvad jeg med et inden for Grundtvigselskabet anvendt udtryk har kaldt den lutherske bodskristendom (Bugge: en art pietisme). Med vilje har jeg ikke selv søgt at give en kirkehistorisk belysning af begrebet så lidt som af dets baggrund i den almindelige religionshistorie, da det kun skulde oplyses ud fra Grundtvigs eget selvopgør, der var mit emne. Men selv når jeg nøjedes med at bruge Grundtvigs egen betegnelse Lutherdommen, skulde sagen dog ikke kunne misforstås. Grundtvigs egen frontstilling efter $183^{2}$ blev tilstrækkelig tydelig - selvom også jeg ligesom P. Th. er klar over bodskristendommens vedvarende betydning for Grundtvigs sprogbrug. Det burde dog undersøges, i hvor høj grad det i virkeligheden er bibel- 
ske tankegange, der i denne retning bestemmer Grundtvigs forkyndelse - Johanneslitteraturen og Paulus. Grundtvig var bibeltro.

Et afgørende punkt i P. Th.s kritik er hans indvending mod påstanden om, at det skulde være en »profan« opdagelse af menneskelivet som Guds skaberværk, der får Grundtvigs kristendomssyn til at kæntre: ». . . netop når udgangspunktet skal være en rent »profan« opdagelse af »livet som man har det for sig«, bliver dets betydning for det nye kristendomssyn problematisk « (s. 583). - Det viser sig her, at det ikke blot er en forskellig tolkning af Grundtvigstekster, der skiller os, men noget principielt: en forskellig opfattelse af, hvad der kan ændre et kristendomssyn. P. Th. vil antagelig hævde, at det kun er under et indtryk af ægte kristendom, et falsk kristendomssyn kan blive til et ægte. Profane indtryk må give profan skævhed. Men dette syn er en teologisk fordom.

Det er ikke blot Grundtvigs tilfælde, der viser det. Det er nok sket nogle gange, at en pietist har måttet aflægge sin pietisme, fordi dagliglivets virkelighed og uomgængelighed, ja, dets »sandhed« overbeviste ham om, at hans religion var falsk; et profant indtryk altså som slet ikke behøvede at bevirke en kristendomsfornægtelse, men som netop kunne berede vejen for det virkelige evangelium, idet der ligesom »faldt skæl fra øjnene« - for at bruge Grundtvigs udtryk. Men selvfølgelig kan en sådan hændelse også føre til aflæggelse af enhver form for kristendom og også til selvforløsningens »bekymring « (jfr. Nordens Mythologis omtale af naturalisterne).

$\mathrm{Vi}$ er her ved spørgsmplet om sekularisering. Mogens Lund har i »Studenterkredsen « 1964 nr. 2-3 været inde på forskellen mellem den, der er en følge af den kristne tro, og den, der hos Grundtvig gør sig gældende, når han taler om menneskelivet »bortset fra troen«. For mig er imidlertid betydningen deraf den samme, og jeg vil gerne her gentage begrundelsen derfor (se »Studenterkredsen« I $_{6} 65 \mathrm{nr} .3$ ):

Der er i hvert fald to muligheder for at få lys over det sande forhold mellem evangeliet og verden. Man kunde sige,, at der i begge tilfælde er tale om en afdæmonisering, i det ene tilfælde af verden, i det andet tilfælde af evangeliet. Den sekularisering, som kristendommen møder verdens forskellige religioner med, betyder en afdæmonisering af verden. Solen, månen og stjernerne er ikke længere guder, men storartede og nyttige fænomener, og den jordiske verden er nu menneskets virkeplads - ingen himmelstige. Det spøger ikke mere, træet er træ, 
stenen sten - jfr. Martin A. Hansens skildring af den romanske kristendoms afdæmoniserende virkning i Norden (»Orm og Tyr «).

Den anden mulighed foreligger i Grundtvigs tilfælde, men bestemt ikke blot her. Han kommer fra en falsk kristendom, hvis evangelium er dæmoniseret: det vil herske over verden og skabe den om efter et himmelsk mønster. Afdæmoniseringen sker her ved, at Grundtvig får øje på menneskelivet som virkeligt, bortset fra troen. Det var virkeligt, før kristendommen blev til, det var det i Palæstina - og i Norden, før kristendommen kom hertil. Denne rent historiske betragtning oplyser for Grundtvig, at evangelium er et, og en menneskelig livstolkning er noget andet. På chokagtig måde får han øje for det virkelige liv og tager gennem sine reflektioner konsekvensen af det skel mellem himmel og jord, der nu træder $\mathrm{i}$ stedet for sammenblandingen. Kristendommen afdæmoniseres, den vil ikke mere herske, men tjene, den er ikke et himmelsk mønster for verdens indretning, men et værgeløst evangelium. Himlen bliver nu virkelig himmel, fordi jorden blev jord. Men derefter kan Grundtvig også gå den anden vej: fordi himlen er himmel, er jorden jord.

Biografisk set er det sandt, at kristendommen i begge tilfælde er forudsætningen for opdagelsen, men i Grundtvigs tilfælde var det en falsk kristendom, der vakte det spørgsmål, om livet da ikke betød noget. Det var kristendommen som historisk fænomen i verden, der rejste spørgsmålet. Uden den havde han heller ikke opdaget menneskelivet, ligesom når skæl falder fra øjnene. Men da det skete, afdæmoniseredes den falske kristendom, og den ægte kristendom afslørede sig for ham. Og opdagelsen af den ægte kristendom betyder så igen bekymringsløshed $\mathrm{i}$ forholdet til det jordiske liv. Ud fra det kan der ikke længere - som i Grundtvigs hedenske ungdom - anvises frelsesveje. Jorden er jord. Men den er Guds jord. Og kristendommen er til for jordens skyld. Gud genføder menneskelivet ved sit ord. Men det kan i stedet for Kristus blive en Mrs. Bolton, der kan give anledning til denne klaring af forholdet mellem evangeliet og verden.

- P. Th. fejer teorien om hende af bordet: »denne mærkelige teori《 $\left(s .5^{67}\right)$. Han har så inderlig ret $i$, at »noget sikkert« ikke kan siges på det foreliggende grundlag, men jeg har også kun søgt efter en rimelig forklaring på en lang række steder i teksterne og kan ikke se, at noget som helst taler imod teorien, uden hvilken adskilligt $\mathrm{i}$ forfatterskabet, ikke mindst Persefonestederne i NM, ikke kan få en 
fyldestgørende begrundelse. Hvor stammer ellers Grundtvigs betagelse i bogens indledning fra, den poetiske tankeflugt, som musen Persefone sætter i gang? Og hvordan går det ellers til, at NM, der oprindelig var tænkt som en indføring i Nordens mytologi, ender som et kampskrift til fordel for en græsk-nordisk kultur P. Th.s antydning af, at H. N. Glausens naturalisme skulde være inspirationen til begejstringen for Grækenland, kan roligt afvises. Den sættes jo netop i forbindelse med Nordens naturalisme i myterne.

Derfor kan jeg heller ikke gå med til, at mindet om Mrs. Bolton i årene I 843-44 skulde have antaget »uforholdsmæssige dimensioner« på gr. af en manio-depressiv bølgegang uden speciel foranledning i hans oplevelser. Jeg vil udtrykke mig tydeligere, end jeg mente der var anledning til i bogen (s. 459 og 462 note 9 ): i sommeren I843 var Grundtvig på sin sidste Englandsrejse, og mindet om Clara Bolton er da væltet ind over ham, hvad der tydeligt prægede hans sølvbryllupsdag derovre. Efter hjemkomsten påbegyndtes Bragesnakforelæsningerne, og de kvindelige tilhørere inspirerede ham til manisk tankeflugt, men samtidig til den skjulte bekendelse til det »fremmede øje« - Clara Boltons - som åbnede hans blik for sammenhængen mellem kvinden og naturen (M.f. s. 223). Ja, siger han i sin afslutning, der kan gerne være »en hemmelig grund « til hans tak til især de yngre kvindelige tilhørere (s. 462). Brage-Snak er simpelthen en skjult hyldest til hans engelske muse. Deraf det maniske drag. Reaktionen herpå følger med depressionen i de følgende måneder. Mødet med fru Hennings i I 844 - hun substituerer Mrs. Bolton - bevirker igen en manisk opblussen og giver anledning til digtet. »Småfruerne«, hvor Constance Leth ganske naturligt inddrages i treklangen, og hvor Grundtvig præcist bestemmer hendes og Clara Boltons betydning for ham: den første fik ham til at føle, at han havde et hjerte, hun smeltede det, og den anden blev hans muse: »Ved dit Smil og ved dit Lyn Vågned op mit Skjaldesyn«. Den tredje frues betydning for ham synes at være en foryngelse, som dog kun postuleres, og som ikke kan efterspores $\mathrm{i}$ forfatterskabet undtagen i nogle erotisk bestemte digte. Nej, denne sidste episode er en udløber af den betagelse og inspiration, der lå 14 år tilbage, men blussede op igen efter den sidste Englandsoplevelse. Under behandlingen af græske og danske myter var stedet til på diskret måde at takke for inspirationen (ikke $\mathrm{i}$ »Mands Minde«, som $\mathrm{P}$. Th. foreslår, men hvor det er de påtagelige Englandsindtryk, der kommer frem. 
Jørgen Bukdahl har (i Dansk Udsyn I964 nr. 3) fuldud tilsluttet sig synet på Clara Bolton som Grundtvigs digtermuse og anfører yderligere nogle tekster, som jeg nok har været opmærksom på, men ikke nævnt - for ikke at kunne angribes på mere tvivlsomme tolkninger. P. Th. mangler Bukdahls sans for Grundtvigs psyke. Til gengæld savner Bukdahl forståelse for de teologiske konsekvenser af Grundtvigs gennembrud, hvad der blandt andet viser sig i, at han som overskrift over udredningen af problematikken hos Grundtvig benytter Anders Nygrens modstilling af eros og agape. Denne modstilling, der især prægede Grundtvigs tankearbejde i $1823-25$, ændredes netop i I 832, hvor han gør op med mytologi og poesi som frelsesveje (eros) og sætter skel mellem human livstolkning og kristendom. Himmelstormen forsvinder dermed fra Grundtvigs filosofiske og kristelige tænkning.

Sin teologiske fordom over for muligheden af, at Clara Bolton gennem sin samtale med Grundtvig kan have haft indgribende betydning for hans kristendomssyn, uddyber $\mathrm{P}$. Th., idet han principielt erklærer dette: »Et sådant profant opgør måtte snarere have ført til en hedensk livsbekræftelse, der helt frigjorde menneskelivet fra kristendommen « (s. $\left.5^{84}\right)$. Ja, det kunde det godt have gjort, men gjorde det altså ikke hos Grundvig. Det førte derimod til hans notabene til enhver kristendomsopfattelse og enhver kirke: menneske først. Men selvfølgelig indebærer en sådan polemik, at han ved, hvad kristendom er. Hans »motto er rettet mod den falske kristendom i den rettes navn, og det er blevet til som følge af hans beskæftigelse med kristendommen. Uden kristendommen som forudsætning opstår en sådan problematik jo slet ikke. Men det er ikke rigtigt, at alle Grundtvigs overvejelser i NM i virkeligheden forudsætter »det kristendomssyn, han allerede var nået frem til« (s. 584). I SB III I83 I er Grundtvig endnu fanget af syntesen mellem tro og erkendelse (M. f s. $9^{8} \mathrm{ff}$ ), hvad der forfalsker troen. I NM er syntesen sprængt. Og følgen bliver en ny forståelse af dåbsordet. Det førte han med sig fra I825. Men jeg må anbefale P. Th. igen at sammenligne forkyndelsen i SB og i Frederikskirken for at opdage forskellen på den kontinuitet, der er m. h. t. Grundtvigs fastholden af trosbekendelsen - og den betydning, denne får $\mathrm{i}$ den helt nye sammenhæng. At hans kirkelige syn »må føres tilbage til 1825 «, er en typisk bemærkning af P. Th., idet den skal imødegå min hævdelse af, at Grundtvigs kristendomssyn bliver nyt i 1832, samtidig med, at den jo er ganske uimodsigelig, når den blot forstås sådan, at Grundtvig i 1825 fandt den trosbekendelse, der 
så 7 år efter fik en helt ny betydning for ham - som det lille ord af Guds mund, der er værgeløst i verden. Det var trosbekendelsen ikke i i 825: både troende og ikke-troende måtte erkende betydningen af, hvad Grundtvig her havde fundet. Den »sakramentkirke«, som han opbygger på det nye grundlag indtil I 83 I, skifter også helt karakter i gennembrudsåret: kirkeinstitutionen er nu af dennesidig art i modsætning til den hellige almindelige kirke. Før sammenblandede Grundtvig tingene. Englandschocket bragte dem på plads.

For de var der jo i forvejen, både troen og kirken, naturen og livet. Opdagelsen består i et nyt lys over tingene. Nyt lys over skaberværket betyder ny tro, nyt kirkesyn, og ud fra dette må der så tales på ny måde om livet. P. Th. lader sig forvirre af de skiftende formuleringer, som tolkningen af de forskellige tekster medfører: snart ses sagen fra den ene kant, snart fra den anden. Men der er ingen modstrid imellem dem. Et eksempel. P. Th. citerer mig: »Samtidig med at Grundtvig på denne måde (i troen på dødens overvindelse) blev kristen, blev han menneske - $\mathrm{i}$ betydningen: fik mod til at være det«. Herudfra konstaterer P. Th. en modsætning til min tese: dette betyder jo kristen først og menneske så!

Ja, hvis man gør Grundtvigs »menneske først« meningsløst ved at tage det ud af sammenhængen - som om det betød: få først mod til at være menneske og bliv så kristen. Nej, når det gælder mod til at leve og dø, så er kristendommen for Grundtvig altid forudsætningen. Men der er jo da her tale om noget helt andet end at få øje på livet som noget $\mathrm{i}$ sig selv (modsat den gamle lutherdom) og så at gøre opmærksom på, at uden den konkrete tilværelse som forudsætning hænger alle kristne ord i luften. Mens der her er tale om konfusion hos P. Th., er der sikkert tale om fejllæsning, når han (s. 585) på samme måde indlæser kristendommen som forudsætning for menneskesynet i disse ord fra min bog: Grundtvig fik »under opgøret med sin bodskristne fortid i lyset af den kristne tro det timelige liv at se som et hedensk-menneskeligt liv, der kunne leves uden bekymring for evigheden - i daglig kamp for det levende mod det døde« (s. 766). Igen: det som troen giver, er bekymringsløsheden. Det kan opdagelsen af det konkrete liv (Clara Bolton og England) ikke give. Men det var ikke hans kristendom, der havde ført ham til denne opdagelse.

At Grundtvig fik øje for menneskelivet, gav stødet til hans sekularisering af billedsproget, historiesynet, det politiske arbejde, folkeoplysningen, videnskaben, kirkeinstitutionen o.s. v.: verden og himlen 
må ikke forveksles. Det er som om han river alt dette ud af kirkens favntag. Med nye øjne afslører han den falske kristendom. Men dette strider da ikke imod, at han, når han taler ud fra den kristne tro, hævder sekulariseringens nødvendighed. I troens lys er verden da netop verden - og ikke himmel. Men som sagt: man kan komme til denne erkendelse ad andre veje end troens. Det gjorde Grundtvig og derefter blev han talsmand for den sekularisering, der er en følge af den kristne tro. Tingene måtte ikke blandes sammen.

Når P. Th. finder adskillige modsigelser i min Grundtvigtolkning, behøver det ikke at skyldes begrebsforvirring fra min side. Det kan også skyldes, at han ikke har forstået de anvendte begreber. Det gælder i hvert fald begrebet sekularisering. Det har for mig været et hjælpebegreb til sammenfatning af alle Grundvigs bestræbelser for at befri kulturen fra den kristianisering, som var hans eget tidligere mål. Det skal altså forstås ud fra Grundtvigs egen intention, ikke ud fra vor moderne verden, hvor ordet kan betyde fornægtelse af kristendommen, løsrivelse fra Gud. Man skelner derfor mellem denne »sekularisme og den sekularisering, der følger af, at kristendom er tro og ikke kulturnorm. P. Th. tager ikke hensyn til dette skel og udbryder derfor gang på gang: hvordan kan man kalde Grundtvigs syn sekulariseret!

Det er hans kommentar til for det første NM. Hviler kulturkampen virkelig her på »hedensk « grundlag? Er der her tale om samarbejde med ikke-kristne? Ja, efter Grundtvigs mening. Og andet drejer sagen sig ikke om. Naturalisterne er efter hans syn ikke kristne, de er hedninger med »ånd «. Sammen med dem vil han bekæmpe ethvert umenneskeligt syn som f. eks. det gennemført biologiske syn på mennesket. Kulturkampen har altså ikke længere kristent fortegn - den er blevet sekulariseret. At $\mathrm{H}$. N. Clausen selv regnede sig for kristen, spiller $\mathrm{i}$ denne forbindelse ingen rolle. $\mathrm{P}$. Th. bliver nødt til at skelne mellem, hvad Clausen og vi andre mener - og så hvad Grundtvig mener.

Når han fremhæver, at jeg selv »må erkende«, at NM ikke helt holdt sin hedenske linie, tænker jeg derfor ikke ud fra et moderne begreb om hedenskab, men på Grundtvigs egen linie. Der er ikke noget underligt $i$, at han under sit store selvopgør vakler noget hist og her. Han er jo på nye veje. Det er ikke sådan straks at klare sondringen mellem tro og anskuelse - at få alt det skilt ud fra den kristne tro, 
som han før har sammenblandet med den. Jeg må altså afvise P. Th., når han $($ s. 587) hævder, at der ikke er tale om sekularisering af skabelsestanken i moderne forstand, for det er ikke det, sagen drejer sig om, og også, når han hævder, at der i NM ikke er tale om samarbejde med ikke-kristne. For det er Grundtvigs bevidste mål. Og det er det, sagen drejer sig om.

P. Th. hævder, at når Grundtvig kan betragte sine kirkelige modstandere som hedninger, skyldes det allerede hans brud med den kristelig-idealistiske syntesetænkning i i 8 Io - det er ikke nogen ny opdagelse. Jamen det nye er hans bevidst positive holdning over for tidens hedninger med ånd, når det gælder kulturkampen. Mærkeligt, at $\mathrm{P}$. Th. ikke kan se, at hans nye sondring mellem rationalisme og naturalisme (med ånd) er af afgørende betydning. At der er ånd uden for kirken er en erkendelse, der er et med sekulariseringen af I 832: begrebet ånd er bevidst taget ud af kirkens favntag. Herfra går linierne fremefter, men de går ikke tilbage. Kan $\mathrm{P}$. Th. påvise en lignende klarhed på et tidligere tidspunkt, falder min tese. Når han hævder, at 1832 var en vigtig milepæl på Grundtvigs »menneskelige« udviklingslinie, men ikke betegner et dybtgående brud, skyldes det imidlertid ikke, at han har fundet noget tilsvarende til den. nye erkendelse i i 8ı. Det skyldes derimod, at han ikke har forstået, hvad han skulde lede efter.

På akkurat samme måde som NM bedømmes Håndbog i Verdenshistorien: læser man denne, »får man unægtelig ikke indtryk af sekularisering eller videnskabelig forståelse i sædvanlig forstand « ( $\mathrm{s}$. 588). Nej, det har jeg heller aldrig påstået. Men når Grundtvig nu går ind for, at en historieskriver hverken må have religion eller fædreland, når han selv vil skrive »upartisk « og kun bygge på de objektive kendsgerninger, så kan man roligt sige, at han selv vil sekularisere sit historiesyn. Også bibelen vil han se på som videnskabsmand. At det ikke sker på moderne vis, er både vist og sandt. Og dog er han forbavsende radikal f. e. i sit syn på Det gamle Testamentes begyndelse. Da hans tilhængere siden gik i kamp mod det moderne bibelsyn, vilde de være blevet forbavsede over Grundtvigs tale om myter i Genesis - hvis de altså havde læst deres lærefader. I mit svar til Michelsen i Gr. st. 1965 har jeg vist, hvordan han omhyggeligt vil udtrykke sig som historiker i sin gennemgang af det bibelske stof. $\mathrm{Og}$ det er dog hans intention, det gælder. »Vil Thaning virkelig påstå, at dette historiesyn ikke er bestemt af »specielt kirkelige synspunkter«« 
(s. 589). Ja, bestemt. Vel at mærke, når påstanden ikke (som hos P. Th.) fremtræder som min vurdering, men som en tolkning af Grundtvigs eget syn på historien: »Det må ikke farves af specielt kirkelige synspunkter« (M.f.s. 294 - ingen henvisning hos P. Th.). Igen: jeg forstår ikke ved sekularisering en udrensning af alt, hvad der har med bibel og kirke at gøre. Historikeren Grundtvig er absolut bundet til bibelens historiesyn (verdensløbet varer i 6000 år o. s. v.) og giver kirken en afgørende plads som faktor i historien, men han gør det ikke som kirkemand, men som videnskabsmand. Der kan ske en afklaring af hans historiesyn, mens han skriver håndbogen (fundet af det græske syn til afløsning af den mosaisk-kristelige anskuelse), men fra starten af er hensigten sekularisering.

Igen citerer P. Th., som om det var min bedømmelse, at grundlaget for håndbogen er kendsgerninger, der »har almindeligt Krav paa historisk og videnskabelig Gyldighed « (s. 590). Kun retskrivningen røber, at det er Grundtvigs egne ord og altså sigter på, hvad han selv søger frem til (M. f. s. 294). Det er uimodsigeligt, at »en kirkelig betragtning ikke bliver almengyldig og »profan«, blot fordi man argumenterer logisk og empirisk for den« (P. Th. s. 590). Men det afgørende er ikke, at man kan kalde Grundtvigs form for videnskab »naiv«, men at forstå hans egen hensigt med at sondre mellem en kirkelig betragtning og videnskab og forstå, at han nu vil gå empirisk til værks. Heri består hans sekularisering af historiesynet. Kan P. Th. finde et andet udtryk, så for mig gerne. Men det skal dække Grundtvigs bestræbelser. Hans eget udtryk »upartisk« dækker ikke.

Det er det samme grundsyn, der præger »Kirke-Spejl«. Grundtvig ved sig også her i modsætning til sine forgængere, som når han taler om romermenighedens svaghed, fordi den i sin folkelige baggrund mangler »hjemlige Forestillinger om et menneskeligt Husliv og Folkeliv« (U.S.X. s. I3I) og tilføjer: »Dette har nu vel vore Kirkehistorikere og i det hele vore skriftkloge sjælden eller aldrig og lidt eller slet ikke lagt Mærke til ...«. Senere hedder det: »Hovedgrunden til alle vore daarlige Kirkehistorier er da den samme som til vor daarlige Teologi og til vor kummerlige Deltagelse i Kristen-Livet: nemlig vor ringe Delagtighed i det ægte Menneske-Liv og det deraf flydende Ubekendtskab med Menneske-Livet, fremfor alt hos os selv.« (s. 20I ). Når han desuden er klar over, at »den rent menneskelige og folkelige Betragtning af den kristne Menigheds kirkehistoriske Levnedsløb endnu sædvanlig anses, om ikke for et rationa- 
listisk Kjætteri, saa dog for et poetisk Sværmeri«, som man må vogte sig for (s. I 59) - så er der begrundelse for min tilføjelse (M.f.s. $696 \mathrm{f}$ ), at han altså selv »opfatter sin kritik af kirken som en historikers og digters kritik på menneskelivets vegne, ikke i første række som en teologisk kritik. Han står uden for kirken og påpeger dens forkyndelses rent menneskelige forudsætninger «.

P. Th. hævder, at jeg hermed mener at ville sekularisere også »Kirke-Spejl« - en noget mærkelig udtryksmåde, da sagen jo drejer sig om, hvornår og hvorvidt Grundtvig sekulariserer. Når han da vil skrive Gudsordets historie (som i K-S.), vil han selvfølgelig ikke sekularisere Guds ord. Det er ganske vist kendeligt i verden, men skal netop ikke adskilles fra troen (sekulariseres): det kan nemlig ikke tilegnes af ikke-kristne uden hensyn til tro. Intet i min fremstilling kan tydes i denne retning. Den understreger derimod den linie i K-S, der bliver stærkere og stærkere $\mathrm{i}$ bogen, at det folkelige er forudsætningen for det kristelige, hvad de skriftkloge, altså teologerne, ikke har forstået. Det måtte der en poetisk historiker til at opdage - og han opdagede det uden for kirken. Men så faldt der også et klart lys ind over Gudsordets historie i verden. Og »et lige så opbyggeligt som oplysende kirkehistorisk Overblik « (X s. 193) må da krones af den erkendelse, at »Herrens og hans Menigheds Maal er det samme som Menneske-Slægtens, den Menneske-Slægt, der er sig selv levende bevidst« (s. 194): det er Menneskelivet, der skal oplyses, forklares og foreviges, det er det, der skal frelses. Men heller ikke det er der nogen, der har fattet mellem apostlene og os. En anden kristendomsopfattelse end den kendte er altså blevet frugten af historikerens og poetens opdagelse. Men Grundtvig tvivler ikke om, at den stemmer med den apostolske forkyndelse af Guds søns komme til verden den han ad sin egen vej er nået frem til at se som forudsætningen for enhver tale om kristendom: den er jo selve målet for Guds frelse.

Det er heller ikke i kirken, han har fået øje for den menneskekundskab, der er gemt i »Nordens mageløse Myter« (X s. 20I). Men ikke mindst $\gg$ Nævnelsen af Odin og Freja midt i Kirkehistorien ... regnes sædvanlig ikke blot til min utilladelige poetiske Tøjleløshed, men vil kjækt blive anført som et soleklart Bevis paa mit Kjætteri og mer end halve Hedenskab« (s. 234). Grundtvig vil, som P. Th. anfører det, fortsætte Det ny Testamentes historieskrivning. Men han ved jo meget vel, at han som digter og historiker må føje noget til, 
for at sagen kan blive klar. Og først nu i »den nordiske menighed « foreligger betingelsen for, at den kan blive det: det folkelige og menneskelige kan nu erkendes som forudsætning for det kristelige ${ }^{1}$ ).

Hidtil har jeg ikke kunnet anerkende P. Th.s kritik. Men der er nu et punkt, hvor jeg giver ham ret: jeg burde grundigere have kommenteret Grundtvigs tanker om kristendom og kultur i begyndelsen af »Den danske Statskirke upartisk betragtet《 I 834. Det er ikke rigtigt, at Grundtvig i denne bog »tillægger kristendommen, præsterne, bibelen og teologien større betydning, end man skulle vente det af en talsmand for et sækulariseret kultursyn« (s. 594) - med mindre man godkender $\mathrm{P}$. Ths. dekret om, at et sådant på moderne vis skal have udraderet ethvert spor af kirken som kulturfaktor, ja, med mindre man identificerer sekularisering og sekularisme. Men når Grundtvig hævder, at »Fæderne-Troens Virksomhed indslutter det Borgerlige Selskabs og Menneske-Udviklingens eneste velgrundede Haab « (VIII s. 66), kan min kommentar dertil anklages for at være for kortfattet og må uddybes. P. Th.s egen kommentar er den, at det jo strider mod min tese: den, at »efter »Nordens Mythologi« skal kristendommen ikke være oplysningens og samfundslivets kilde, den der helliger båndene og redder kulturen fra opløsning, selvom dens kulturelle betydning er åbenbar« (M.f. s. 48I - for forkortet gengivet af P. Th. s. 592$)$.

Man bedes imidlertid bemærke, at der $\mathrm{i}$ citatet står »skal være«, og at det betyder noget normativt. Formuleringen refererer nemlig til kultursynet i »Skal den Lutherske Reformation ... fortsættes 《 I 83 I. Der er i I 834 tale om et håb, det eneste, der ud fra historien kan

I. I anledning af »Kirke-Spejl《kunne man i øvrigt bemærke, at bogen tydeligt illustrerer min påstand om, hvad der er »dødvægten《i Grundtvigs tankegang. Når han f. e. postulerer, at den kristelige livskilde i Grækenland er udtørret, fordi grækerne har kasseret den apostolske trosbekendelse, er det fuldstændig følgerigtigt ud fra hans mageløse opdagelse, men samtidig viser det, at hvis man under tolkningen af hans forfatterskab følger hans egen anvisning på, hvorudfra man skal forstå det, så kommer en fiks idé til at overskygge hovedsagen (jfr. M.f.s. 703 og 725). Man kan kalde dette for en vilkårlig påstand fra min side, og dog er det et syn på forfatterskabet, som nok skal stå sin prøve.

P. Th. mener, at jeg under gennemgangen af den første prædiken i 1832 er gået forbi det, som Grundtvig selv anså for hovedårsagen, nemlig opdagelsen af I 825. Men det gør jeg selv udtrykkelig opmærksom på (M. f. s. 5 I 7). Senere følger så den bebudede redegørelse for det nye dåbssyn (M.f. s. 539 ff), det, som frigør den polemik mod bibelkristendommen, der ikke er en umiddelbar følge af I $_{25}$, hvad P. Th. mener (s. 578). 
gives gode grunde for, mens det i 183 I er den gammeldags lutherske prædikant og moralist, der henviser til Herrens forjættelser og vantroens nedbrydende magt. Man er $\mathrm{i}$ to forskellige verdener, når man læser de to bøger, og de enkelte sætninger skal nøje fortolkes ud fra den helt forskellige sammenhæng.

Også i i 83 I ses der på statens interesse i at beholde de gammeldags kristne i kirken. Men begrundelsen er primært bibelsk, er dén nemlig, at Herren velsigner, »for sine Troendes Skyld, hvert Land og Rige som vil huse og hæle dem, ja lader Ingen ubelønnet, som rækker dem en Lædske-Drik, fordi de er hans Discipler« (V s. 310). Men vil man nu i vore vantro dage ikke tro det, så »troe Man dog sine egne Øine: at christelig Fromhed udklækker og opelsker alle borgerlige Dyder, medens vantro Selv-Klogskab bandlyser og udrydder dem, ja, med eet Ord, at Christendommen styrker og helliger alle Troskabs og Kiærligheds Baand, medens Vantro overhugger dem, den ei kan opløse«. - I I 834 henvises der ikke til Herrens løfter, og der tales ikke om den kristne fromhed, der alene opbygger, mens vantroen nedbryder. Det er historikeren, der taler, ikke længere bodsprædikanten: øvrigheden måtte ønske, »der i hver Kirke stod nu en gammeldags christelig Præst, med Tro og Aand og Salvelse, som med det mægtige Ord, der oplyser Øine, og opliver Sjæle, kunde indgyde de forsamlede Skarer ogsaa kun en Gnist af den hellige Ild, der opløfter Sjælen over Øieblikket ...« (V s. 3I3). Sådan kunne Grundtvig ikke tale i 1834 .

Det samme gælder flg. - bemærk den patetiske diktion: »Det er Christendommens umiskiendelige Fortrin for alle Religjoner, og ret egenlig det Guddommeligheds-Præg, den for Tæankeren bærer til Skue, at den ikke blot berører, men uopløselig knytter sig til Alt hvad der med Føie kan kaldes ædelt, stort og elskeligt hos Mennesket « (V s. 3I5). Ganske vist er det dens »Hoved-Sag« at trøste de dødelige med det evige liv, men den kunde ikke være en Guds kraft til salighed, hvis den ikke »oplivede alt det i Mennesket der er af Gud, og stræbde øiensynlig at reformere Menneskelivet, efter det ophøiede Mønster, som selv i den naturlige Tilstand svæver de Bedre for Øine.« - Menneskelivet skal løftes opad, skal reformeres efter det kristne ideal. Kristendommen er norm. Det er den ikke mere efter I 832 - og heller ikke i i 834 .

Til forståelse af tankegangen i skriftet om statskirken er det nyttigt at fremdrage et udkast betitlet »Statsmæssig Oplysning« (fasc. $33^{6}$ 
se Bugge s. 26 I ff), der uden tvivl er skrevet umiddelbart efter $\gg$ Den Danske Stats-Kirke . . .«, som har fået »imprimatur« 23. 6., mens der hentydes til udkastet i »Den latinske Stil«, der blev trykt I3. 7. (se Bugge s. 264 note I6). I »Statsmæssig Oplysning « er der intet spor af kultursynet i 183 I. Det er som blæst bort. Men der er fuld kontinuitet med I 832 - Nordens Mythologi.

$\mathrm{Nu}$ sættes den selvkloge fornuft i modsætning til fantasi og følelse - ikke til troen. Andelig og hjertelig oplysning er nu, hvad Grundtvig kæmper for til samfundets gavn. »Den Poesie, der er i Folkets Aand ... er ... ubetalelig og bør med al Anstrængelse hindres fra at uddøe, ved at sættes i den frieste Virksomhed, til Udvikling af en beslagtet Oplysning og Formildelse af de skarpe Vadsker i Stats-Legemet«. - Over for de skarpe vædsker kaldes kristendommen nu ikke mere til hjælp. Men Grundtvig er klar over, at hans fortid vil hindre ham $\mathrm{i}$ at råbe folk op - og man kan egentlig ikke fortænke dem $\mathrm{i}$ at have svært ved at fatte, at han pludselig er blevet en anden (jfr. den desorienterede H. N. Clausen efter det kirkepolitiske omsving, M.f.s. 483). Han siger: »... naar ikke den kirkelige Forvirring havde sat mig i skævt Forhold til den dannede Verden, skulde jeg sikkert overbeviist den om, at jeg tænkde rigtig om Almue-Oplysning ...

Hvad der skal modvirke kulturens opløsning, udtrykkes nu helt anderledes end i r 831. Det er nemlig »Tro paa Guderne, Ærbødighed for Øvrigheden, Lydighed mod Loven, og Agtelse for alle de selskabelige Forhold, hvormange Indskrænkninger, Opoffrelser og Savn de end paalagde Enkelt-Manden«. Det er det, Grundtvig i »Den Danske Stats-Kirke ...«kalder »det Religiøse Element« (VIII s. 64). Religionernes borgerlige side - også kristendommens - er skilt ud fra selve troen. Begrebet omvendelse er blevet sekulariseret: »Man seer let, det er ingen Kirkelig, men en Borgerlig og Menneskelig Omvendelse her tales om, ikke en Omvendelse for det andet, men for dette Livs Skyld, ikke en Forvandling af Hjertet, men en Forandring af Tankegangen, og ingen Opgivelse af Oplysning, men en Frugt af Oplysning om hvad der tjener os bedst.

Vist nok er det min Tro, at denne Borgerlige Omvendelse af »Børnene til Fædrene« og af Selvklogskab til sund Menneske-Forstand vil ikke lykkes i noget Land, hvor ikke en kirkelig Omvendelse hos Endeel baade baner Vejen, udvikler Indsigten og styrker Forsættet, men hvad kommer min Tro Staten ved, der ligesaa lidt kan give den til 
en Anden som tage den fra mig, og som trues alt for nær af Faren, til at kunne vente paa, hvad Tro kan virke i det skjulte. StatsKlogskab ... lægger Haand paa Værket i samme Øieblik den indseer Nødvendigheden«. Derfor anbefaler Grundtvig over for kulturkrisen - som i i 832 - sin borgerlige højskole.

Det ufuldendte udkast ender i betragtninger, der muligvis fører frem til et andet udkast »Om Borgerlig Dannelse « (fasc 347, 2, se Bugge s. 263), der begynder sådan: »Man lider allevegne af en stor Dunkelhed i Begreberne om de tre vigtigste Ting paa Jorden, som vel burde staae i langt mere levende Vexel-Virkning end nu er Tilfældet, men som netop derfor aldrig maatte forvexles med hinanden, da deres Virksomhed derved geraader i en farlig stor Forvirring. Disse tre Ting er naturligvis det Kirkelige Samfund, det Borgerlige Selskab og det Lærde Væsen, eller Kirke, Stat og Skole, der tilsammen omfatte alle vore menneskelige Forhold ...« (jfr. fasc. 332, 4, Bugge s. $26 \mathrm{I}$ ).

Disse citater fortsætter uden videre det kasserede sted fra trykms. til NM (M.f.s. 259 f), hvor han udvikler forskellen på tro og anskuelse: »Troen er en egen Sag, og ret egenlig hvert enkelt Menneskes egen Sag, og ... hvis Nogen af jer har Lyst til at vide, hvordan min Troes Sikkerhed paa det evige Liv udtaler sig, de maae enten spørge mig derom, eller høre efter, naar jeg ved given Lejlighed taler derom, thi naar jeg taler eller skriver som Borger, som Skjald eller VidskabsMand, da er det ikke Tid eller Sted enten til at præke eller skrifte, saa naar jeg før har gjort det, var det en Feiltagelse, der kun lader sig undskylde med det alt for gamle Vilde-Rede i vore Kirkelige, Borgerlige og Videnskabelige Forhold, der naturligviis forplantede sig til vore Hjerner, og var ikke nemt at klare«.

Der er således kontinuitet mellem I832 og $1834-$ og et brud i forhold til I83I, hvor sammenblandingen raadede. Her var kristendommen rettens og sædernes garant og afgav mønstret for den nødvendige reform af menneskelivet. Den alene helliger båndene og redder kulturen fra opløsning. »Oplysningen maa i det Mindste middelbart være Christendommens Værk, fordi den alene opretholder Retssansen og forhindrer Sæderne $\mathrm{i}$ at fordærves«. »Dens Følger er det eneste Tilfælde i sit Slags« (V s. 316). Denne tankegang er forladt i »Den Danske Stats-Kirke ...«- uanset P. Th.s påstand om det modsatte.

Hvad vil Grundtvig med dette skrift? Han vil have sognebåndet 
løst, så han kan blive i statskirken. »Den herskende Kirke« skal bekæmpes, der skal være fuld frihed i kirken, regeringen må ikke tage parti for nogen, heller ikke for »Fæderne-Troen«. Grundtvig vilde i I 83 I forlade statskirken sammen med de gammeldags troende, men nu ønsker han, at alle skal kunne blive i den, og derfor gælder det om at overtale staten til at åbne »en fri Virke-Kreds i Stats-Kirken« for fædrenetroen, samtidig med at der gives fuld frihed i forhold til ritualerne. Men det, der er anledningen til hans skrift, muligheden for at ritualerne vil blive moderniserede og samtidig tvungne, vil umuliggøre de gammeldags troendes forbliven i kirken.

Det, det altså gælder om, er at overbevise myndighederne om, at fædrenetroen er uundværlig i statskirken. Ikke mere som garant for sæderne eller norm for samfundslivet og dets reformering, men som indirekte inspiration for borgerlivet. Som historiker må han derfor pege på, hvad fortiden viser angående »det Religiøse Elements« betydning for det borgerlige selskab. Historien er nu ikke længere normgivende, men er blevet en kilde til oplysning om det »virkelige« (jfr. Indledningen), der ikke mere skal omskabes. Den kan blive til hjælp for statsklogskaben.

Først udskiller han (som i I 832), hvad »Religjonen« er for ham som individ (han siger udtrykkelig ikke den kristne tro som i I83 I) - det er en privat sag, og peger i stedet på dens borgerlige side (VIII s. 62). I I83 I var det Helligåndens værk, at kristendommen havde en »en velgiørende Indflydelse paa Borger-Samfundet og Oplysningen i Verden (V s. 3I5 f). Den skaber gennem de helliges samfund menneskekærlighed og dermed gode borgere. Når blot tusinde »røres tilbunds af det levende Guds Ord «, gribes mer end ı oo.ooo så meget deraf, at de bliver »gode, gavnlige, flittige, rolige Borgere og trofaste Undersaatter ... en uberegnelig Stats-Vinding til alle Tider $\ll$ og hvad da ikke nu! - Kristendommen er i i 83 I en neddæmpende magt, der er grader af tilegnelsen af den. Blot »en Gnist af den hellige Ild«, »en Draabe« af livets flod vilde have statsgavnlig virkning. Men denne graduering af både evangeliet og den enkeltes grebethed røber bodsprædikanten, for hvem tilegnelsen er en proces, som prædikanten »med Aand og Salvelse s skal fremme, og hvis højde og dybde kan måles. Hvad evangelisk tro er, bryder først igennem i $1832 . \mathrm{Nu}$ afsværges prædikantens midlerstilling, og Helligånden alene virker troen, men skal ikke mere omskabe det borgerlige samfund. Sammenblandingen er ophørt. 
Derfor kan Grundtvig nu som historiker få øje på det fælles for de forskellige religioner, kristendommen indbefattet. »Fæderne-Troen « var også i Grækenland og Rom kilden til kraften i det borgerlige samfund. Men de gamle religioner kan ikke genoplives. Når de ikke kunde det i de gamle lande, kan det heller ikke ske i Norden - en rent empirisk betragtning (V s. 63). Men ligeledes kan det empirisk fastslås, at »vor Fæderne-Tro« ikke kan bedømmes på samme måde som grækernes og romernes, fordi den »to Gange har gjort større Ting end Disse og kan da ikke blot muelig, men rimeligviis gjøre ligesaa den tredie Gang, hvor den faar Lov til at gjøre sit Bedste« (s. 64).

Her er ethvert postulat i kristendommes navn borte. Der er ligefrem en demonstrativ tilbageholdenhed i forstærkelsen af ordet »muelig « til - »rimeligviis«. Historikeren har nemlig erstattet prædikanten. Og han må ikke som historiker have religion - skal kun iagttage (Grundtvig har skrevet sekulariseret historie et helt år, fra midt i I832 til midt i 1833 !). Han konstaterer da, at den kristne tros første heltegerning, folke- og samfundslivet under Valdemarerne, jfr. Saxo, kæmpeviserne og de gamle love, har »noget vist Over-Naturligt« ved sig: troen kom jo udefra og slog dog rod i folket. Det er imod de historiske love, som Grundtvig ellers kender. Ja, overalt, hvor kristendommen mødte tyske eller nordiske folk, blev den »det Religiøse Element $i$ et langt mere udviklet og prydet Borger-Liv, end de ved Hjelp af deres Arilds-Tro havde ført«. Et lige så stort mirakel - stadig historikerens udtryk, ikke den troendes - blev reformationens virkning: fædrenetroens oplivelse »smelter sammen « med det nye tidsrum i statens og skolens historie. Heller ikke her efterspores den indre forbindelse nøjere.

På dette historiske grundlag kan han da gå et skridt videre, men gør det så lidt postulerende som muligt: »... neppe kan det da med Rette kaldes sværmerisk, Haabet, jeg nærer«, om at den religiøse ligegyldighed kan finde en åndelig modvægt i fornyet begejstring for kristenhedens fædrenetro, som kan afværge ligegyldighedens følge for det borgerlige selskab (s. 65). Som historiker er han dog fuldt opmærksom på »det Slibrige saavelsom det Skrøbelige« i forholdet mellem fædrenetroen og folkeliv og stat. Han er jo blevet upartisk og kan se sagen fra to sider, mens han som prædikant før kunne udrede forholdet uden vaklen. Så han ser også godt de særlige vanskeligheder, der foreligger i den nuværende krise, der svarer til den, der i de gamle statssamfund bevirkede folketroens undergang. Filosofiske 
grublerier kan lige så lidt som dengang erstatte fædrenetroen, og skønt selv, poetisk talt, en præst for Nordens gamle guder, tror han dog ikke, at de kan leve op igen. Så er der kun to muligheder: enten må han opgive sit »fædrelandske Haab om Folke-Livets kraftige Fortsættelse og en deraf udspringende Nordisk Oplysning «, eller han må knytte det til håbet om, »at Fæderne-Troen, der har oplivet alle mine Anskuelser, Ønsker og Kræfter, også med den Frihed, der er Aandens Element, kan og vil giøre sin tredie Helte-Gjerning til en Gjenfødelse af Borgerlig og folkelig Vidskab, der danner en ligesaa underlig som glædelig Modsætning til den aandelige Død og Opløsning, alle Varsler spaaede« (s. 66). Ganske vist kan han ikke forlange, at andre end de, der deler hans tro, skal dele hans håb om dens virkninger, men ligeså »billigt« det vil være at lade fædrenetroen virke »det Lidet eller Meget, Den, efter sine mageløse Bedrifter, endnu maatte være istand til«, lige så statsklogt vil det være på alle mulige måder »at fremme den Troes Virksomhed, der, efter et Aar-Tusindes umistænkelige Vidnesbyrd, indslutter det Borgerlige Selskabs og Menneske-Udviklingen eneste velgrundede $\mathrm{Haab}$ «.

Når disse ord læses som fortsættelse af det foregående og ikke tages ud af sammenhængen, er det uberettiget at sige (som Bugge s. 26o), at de virker som »en genoptagelse af et forlængst tilbagelagt standpunkt«. Og det er misvisende eksegese at sige som P. Th. (s. 595 noten): »... både ud fra troens, historiens og statsklogskabens synspunkt hævder han klart kristendommens nødvendighed for samfundslivet. Skønt det i og for sig er to forskellige ting, er fædrenetroen dog en betingelse for den rette historiske oplysning, og det er de troende præster, der skal inspirere den«. Han »skelner ... ingenlunde skarpt mellem tro og anskuelse, kristendom og samfundsliv« (s. 594).

Jo, han skelner. Han dekreterer ikke mere i troens navn. Som troende har han sit private håb, som kun medtroende deler. Og som historiker kan han kun pege på erfaringer. Dem henviser han statsklogskaben til for at få fædrenetroen bevaret i statskirken. Der er noget besværgende over hans henvendelse. Det vil være billigt at lade den få sin chance uden at man kan sige, hvor lidt eller hvor meget der kan komme ud af det. Det vil være klogt - historien vidner om, at intet kan være klogere.

Før hævdede prædikanten, at vantroen nedbrød og opløste og kun troen holdt samfundslivet oppe: den var nødvendig for kulturen. Men Grundtvig kender fra sin ungdom den afgørende modsætning mel- 
lem nødvendighed og frihed. Og nu, efter at tvangen $\mathrm{i}$ hans tanker er hævet, fordi troen ikke længere er lov og norm, men evangelium, nu ved han, at alt, hvad der har med ånd at gøre, kræver frihed. Derfor er det, at han ikke mere kan dekretere i troens navn, men kun håbe, at fædrenetroen »med den Frihed, som er Aandens Element«, vil gøre sin tredje heltegerning til genfødelse af borgerliv og videnskab. Det er ikke en kristen genfødelse, der er tale om, men en kulturel genfødelse (jfr. den borgerlige omvendelse). Og hans håb derom er værgeløst: det vil »neppe« »med Rette« kunne kaldes sværmerisk, han har jo historiske erfaringer at henvise til. Fædrenetroen har jo »oplivet« ham selv, hans anskuelser, ønsker og kræfter, ligesom det danske folkeliv. Der er ikke tale om en reform efter et højt kristeligt ideal, men om en virkning i »Frihed «. Derfor kan man ikke påvise nogen nødvendighed, nogen bestemt nødvendig sammenhæng mellem den kristne forkyndelse og den menneskelige og borgerlige oplivelse, jfr. de to tidligere heltegerninger. »Rimeligviis« vil derfor også fædrenetroen for tredje gang kunne oplive samfundslivet og menneskeudviklingen. Lige så retfærdigt det vil være at give den muligheden, lige så statsklogt vil det »dog nok ogsaa« være at lade den frie virksomhed forsøge sig. Hvor er den postulerede »nødvendighed $\ll \mathrm{i}$ dette? Hans eget private håb kan staten ikke tage hensyn til. Men Grundtvig henviser til de 1000 års virksomhed i landet. I I 83 I kunne han ikke tjene de vantro i kun at bedømme kristendommen efter dens borgerlige virkninger ( V s. 3I5). Nu er det kun dem, han anbefaler staten at se på. Før var kristendommen en nødvendig betingelse for al oplysning. Det ville være »latterligt« her at tale om »Tilfælde« (s. $\left.3^{\mathrm{I}} 6\right) . \mathrm{Nu}$ kan intet postuleres mere. At fædrenetroen indeslutter kulturens »eneste velgrundede $\mathrm{Haab}$ «, er ikke nogen troens påstand. Personligt tror han, at den borgerlige omvendelse ikke vil lykkes, hvor ikke en kirkelig omvendelse »hos Endeel« baner vejen, udvikler indsigten og styrker forsættet (som hos ham selv), men denne tro kommer jo ikke staten ved. Den skal kun give troen fri til at virke det lidet eller meget den »endnu maatte være istand til«. Det er som historiker og ikke som prædikant, han udfordrer statsklogskaben til at indrømme, at fædrenetroen er samfundets eneste velgrundede håb.

Denne afgørende forskel mellem prædikanten og historikeren svarer nøje til skellet af 1832 mellem tro og anskuelse. Forskellen på situationen dengang og nu er den, at Grundtvig for den fælles kulturkamps skyld så vidt muligt skød troen ud af billedet og fremhævede 
anskuelsen som det fælles kampgrundlag. Men nu må troens mulighed for at inspirere kulturelt fremhæves, fordi man truer med at borttage fædrenetroen muligheden for at blive i statskirken. En sag for sig er det, at den alligevel ville skænke staten »sine bedste, flittigste, troeste og lydigste Borgere $\ll$ (VIII s. 66), men det som var det primære i i 83 I (V s. 316), er nu ikke det afgørende, derimod det, at den ville blive langt mindre frugtbar for »Boglig Konst« og tabe det meste af sin indflydelse »paa Folket $\mathrm{i}$ det Hele«, altså sin kulturelle indflydelse. I virkeligheden tænker Grundtvig på sin egen indflydelse. $\mathrm{Nu}$ skulde han jo netop til at realisere kulturkampen.

Faren driver over, så argumentationen i »Den Danske Stats-Kirke« behøver ikke siden at gentages. Men ofte kommer han tilbage til den »fri« eller »levende« vekselvirkning mellem kristendom og kultur. På baggrund af den principielle adskillelse ser han alle muligheder stå åbne. Når der er frihed, er alt muligt. På den anden side er der også kontinuitet mellem I834 og i 832, hvor han f. eks. i et udkast til NM dunkelt taler om, at »den christne Kirke-Aand « omsvæver os under forsøget på at genoplive videnskabeligheden (M. f.s. 242). Det er de konkrete opgaver, der efterhånden melder sig, der nøder Grundtvig til at klare tankerne. Og det er rigtigt, når Bugge fremhæver de rådgivende stænderforsamlinger som årsagen til, at han i skoleskrifterne nøjere trækker skellet op mellem kirke, stat og skole. Men skel-

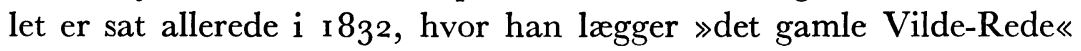
på dette felt fra sig. På grund af »Den Danske Stats-Kirke« at ville flytte »omvendelsen til menneskelivet« hen til skoleskrifterne er hen i vejret (P. Th. s. 596).

Der er for resten også udvikling i skriftet om kirken. Grundtvig er overbevist om, at sognebåndets løsning vil løse alle problemer i den, og derfor behøver han ikke så stærkt at argumentere for de gammeldag troende præsters afgørende betydning. Han mener nemlig (s. 75), at en lovfæstet frihed i kirken »sikkert ikke mindre hos Præsterne af Fæderne-Troen end hos de Andre, vil bære velsignede Frugfor Sædeligheden, for Folke-Dannelsen, og for al Videnskabelighed «. De gammeldags præster får altså ikke mere i denne henseende tildelt en større rolle end de andre. Han har simpelthed glemt, at fædrenetroen lige før var samfundets og kulturens eneste velgrundede håb! - Og der er et svælg mellem I834 og I83 I.

Efter at Grundtvig nemlig over for staten har argumenteret for fædrenetroens forbliven i kirken, drejer sagen sig om at belyse, hvor- 
dan kirken bliver folket forhadt, hvis der ikke er frihed i den, og endelig om at slå fast, at statskirken er uundværlig for staten. Det skyldes ikke, at dens præster indskærper »blind Lydighed mod Øvrigheden (s. 9o) - det skal man ikke lægge for megen vægt på. De gammeldags præster vil altid indprente lydigheden som en samvittighedssag, men dels vil de endnu vissere gøre det uden for statskirken end i den, dels gavner det kun mellem deres trosfæller, som er de færreste. Mængden vil derimod ikke vise mere lydighed, end den nødes til eller har fordel af. - Sammenlign de I00.000, som den lutherske prædikant i i 83 I mente, han havde indflydelse på!

3 år før var det troen alene, der skulde forebygge selvklogskaben og selvrådighedens følger. $\mathrm{Nu}$ er det oplysningen - det har det I 8. årh. ret i! Jo, Grundtvig er blevet en anden siden I83 I. Nu siges det som en indrømmelse, at det vist nok er »meget sandt, at Christenhedens Fæderne-Tro har det store Fortrin for enhver Hedenskabets Tro, at den avler en tilsvarende Oplysning, som er Staten i Forstands-Tiden langt meer end Guld værd « (s. 9I ). Det nytter blot ikke staten, hvis den påtvinger folket fædrenetroen. Betingelsen for, at den kan gavne, er den, at »Troen ansees borgerlig for en Bisag og Oplysning for Hoved-Sagen i Stats-Kirken« (s. 92). Man havde i det i 8. årh. mere ret, end man vidste, når man hævdede, at var præsterne nødvendige, var det for »Skolens« skyld. Grundtvig siger selv, at man »ved at forsømme Oplysningen, forsmaaer det eneste kraftige Middel til at forebygge de naturlige Følger af den Selv-Klogskab og Selv-Raadighed, Man umuelig kan udrydde og ved Magt-Sprog kun forbittrer « ( gof.) - Vi er her langt fra I83i, men vi har også fået præciseret, hvad Grundtvig i skriftets begyndelse forstod ved fædrenetroens kulturelle betydning: den avler en beskeden, historisk oplysning, der virker formildende og forbedrende på den modsatte (s. 92), og så længe fædrenetroen er i levende vekselvirkning med verden, vedligeholder og fremmer den »den universelle Videnskabelighed, der, indskrænket til Christenheden, giør Fæderne-Troen udødelig Ære, og er det Eneste, der kan føre til en grundig Forklaring af Verden og Mennesket« (s. 93). - Ikke mindst her er Grundtvig på hjemmebane. Han ønsker derfor brændende stadig selv at være i levende vekselvirkning med verden - i kulturelt samarbejde med »Folk med Aand «. I udkastet »Statsmæssig Oplysning « udvikles tanken om det nordiske universitet og dets arbejde på at nå frem til en menneskeforklaring ud fra bevidstheden om mennesket som en gåde. Fædrenetroens med- 
virkning påkaldes ikke. Heller ikke i det forudgående skrift om kirken er den en betingelse for oplysningen som i i 83 I (P. Th.), men den er med til at vedligeholde og fremme den og får derved udødelig ære. Uden den var Grundtvig selv ikke blevet ført til sine universalhistoriske syner - dem han nu har skilt ud fra troen.

Det har han gjort, idet han her går i et frit samarbejde med naturalisterne. Og staten vil sørge for en uundværlig folkeoplysning og den grundigst mulige videnskab, hvis den vil beskytte fædrenetroens præster ved siden af »allehaande andre Skrift-Kloge« (s. 93). Gør den det, vil den videnskabelighed, »der er hele Menneske-Slægtens store Anliggende«, lyse fred og udbrede held over staten, så længe »Menneske-Aanden« mægter noget, og forsynet ikke glemmer verden. Det er en radikal vending (omvendelse), at Grundtvig ikke mere lader Herren velsigne det land, der vil huse de troende ( I831), men lader den universelle videnskab lyse fred og held over den stat, der »opammer den i sit Skiød og opholder den i sin Kirke«.

Det sidste gør den ved at holde tvisten mellem præsterne ved lige. Bibelen kan udlægges forskelligt med hensyn til fædrenetroen, men Grundtvig gør et forsøg på - ud fra sin adskillelse af tro og anskuelse - at uddrage af bibelen et fælles udbytte: den historiske side af den kan sætte mange tanker i gang, og dens sædelære sat i forbindelse med »Natur-Religionens Hoved-Sandheder $\ll$ vil ligeledes tjene statens interesser - og det er det, det her kommer an på. Det er »det Religiøse Element« $\mathrm{i}$ bibelen, der er statsgavnligt. (Med henvisning til min bog (s. 494) hævder P. Th., at det næppe er tanken, at oplysningen ikke må være »kristelig«. Jeg har intet sagt om, at den ikke »må være« det, men kun, at der her ikke er tale om kristelig oplysning. Man kunde sige, at Grundtvig har forsøgt at sekularisere det religiøse element: skille det ud fra spørgsmålet om tro).

$\mathrm{Nu}$ er det ikke længere specielt fædrenetroen, der er uundværlig i statskirken, for det er selve kappestriden, der fører til den statsgavnlige oplysning. Lige meget, om man drev fædrenetroens tilhængere eller det Clausenske parti ud af kirken, »da standsede Man den gavnligste og høiest stilende Oplysning, der nogensinde spirede i Christenheden, før den endnu ret fik Tid til at giøre sig kiendelig ...«. Den er ikke afhængig af tro, men af striden mellem folk af forskellig tro. Sådan er selve den brogede statskirke en afgørende kulturel faktor, hvad der konkretiseres på forskellig vis. De skriftkloge er f. eks. nødvendige på den folkelige højskole »for at give Oplysningen det reli- 
giøse Præg, den ei maa fattes« (s. 94). Påstanden gentages ikke i højskoleskrifterne, men ikke fordi Grundtvig først da har omvendt sig til menneskelivet og skilt oplysningen ud fra troen. For »det religiøse Præg « er skilt ud fra troen, og oplysningen er blevet sekulariseret. Nej, påstanden blev fremsat, fordi statsklogskaben på enhver måde skulde overbevises om, at en hensigtsmæssigt indrettet kirke vilde være uundværlig for staten. Grundtvig er i »Den Danske Statskirke« strateg - som jeg allerede ved disputatshandlingen svarede P. Th. i anledning af de særlige påstande i dette skrift. I det øjeblik han derefter tager fat på »Statsmæssig Oplysning«, er han på nyt felt - og alle argumenterne i skriftet om kirken er forsvundne. $\mathrm{Nu}$ ser han kun på, hvad staten selv på direkte måde bør gøre for oplysningen. Den skal ikke vente på, hvad troen »i det skjulte« kan »avle« i denne henseende.

Det er ikke så sært, at P. Th. ud fra det syn på forholdet mellem kristendom og kultur, som han (fejlagtigt) har fundet i skriftet fra I 834, finder det inkonsekvent af mig at påpege senere uklarheder hos Grundtvig. Men f. eks. hans påstand fra $185 \mathrm{I} \mathrm{om,} \mathrm{at} \mathrm{kristendom-}$ men kan skabe »et himmelsk Borgerliv paa Jorden« (M. f. s. 640) har ingen paralleller andetsteds, så jeg må fastholde min tolkning af stedet som et skridt til siden. Men hvorfor skulle Grundtvig ikke enkelte gange kunne komme ud af sit spor? Som regel finder han hurtigt benene igen, hvad han også gjorde i den pågældende artikel.

En udtalelse fra I 864 om gensidig afhængighed mellem kristendom og folkelighed rummer ikke noget dekret angående kristendommens nødvendighed for sand folkelighed. P. Th. refererer mig sådan, at stedet $\gg$ bryder . . . den klare linie fra $1832 \ll-$ men jeg skriver: »synes $\ldots$ at bryde ...«(s. 712). Kristendommens »Hjelp« til folkelivet betyder nemlig ikke en kristeliggørelse af det, men en frigørelse (s. 716). Også i sin alderdom holder Grundtvig linien. Kristendom er ingen norm. - En »noget uklar samarbejdstanke«, som jeg (s. 732) har fundet nogle steder i i 86oerne, klares, når den udarbejdes konkret. Og den har ingen parallel i i 834 .

Ikke mindst besynderligt er det, at $\mathrm{P}$. Th. vil sammenligne det manisk bestemte og derfor uklare fragment fra I865 (M.f.s. 7 I 6 f) med »Den Danske Stats-Kirke«. Her hævdes det, at »dette, at kun den lyslevende Christendom med Christus, ligesaavel kan og vil historisk oplyse og forklare, som den naturlig omfatter og udtrykker hele 
Menneske-Livet, det udviser, at de høinordiske Folke-Stammer ligesaa vel til den menneske-historiske Oplysning, der er deres Kald som til Folke-Livets kraftige og daadfulde Fornyelse, netop behøver endnu mere Christendommens kraftige Hjelp end den behøver dens frivillige Tjeneste«. I dette citat finder P. Th. netop hovedtanken i I 834, det, der var kristendommens fortrin for enhver hedensk folketro.

Men her er dog tale om troen, den lyslevende kristendom med Kristus, og ikke om fædrenetroens kulturelle virkninger, dens historiske og religiøse side. Til den menneskehistoriske oplysning kræves der mere end kristendommens frivillige tjeneste, der kræves lyslevende Kristustro. Det er en dogmatisk påstand. Oplysningen er da også af noget andet art end i 1834 , idet Grundtvig i fragmentet skuer ind i gudernes lag, der hvor man »firkanter (kvadrerer) Evighedens Cirkel og udregner Kiærlighedens Kubik-Indhold« (M. f. s. 7 I 7 ). - Det var kun to år før manien palmesøndag 1867 helt tog overhånd. Da fantaserede han også om cirklens kvadratur.

P. Th. og Bugge er enige om at tage afstand fra det syn, at der $\mathrm{i}$ I $831-32$ er tale om en »engangsomvendelse $\left.\ll^{2}\right)$. Bugge hævder, at der er tre stadier $(1832,1834,1836)$ med meget løsere indre sammenhæng, end jeg regner med. »I visse af de mellemliggende år synes afklaringsprocessen vitterligt at være gået i stå, hvad der er ejendommeligt, dersom nybesindelsen i ${ }^{8} 83$ - 32 skulle have været det egentlige igangsættende for den endelige afklaring« (s. 255). Men for det første tager Grundtvig umiddelbart etfer afslutningen af NM fat på sin håndbog $\mathrm{i}$ verdenshistorie - til gavn for ungdommen, han fortsætter den danske rimkrønike, og han skriver i 1834 de nævnte trykte og utrykte ting, hvis hovedtanker udspringer af »engangsomvendelsen«. Som eksempler nævner jeg nogle motiver fra den første del af »Statsmæssig Oplysning《: Mund kontra pen, den åndelige og hjertelige oplysning af hele menneskelivet, det antropologiske syn (for-

2. Ingen af dem præciserer nøjere, hvad de selv mener der sker under udarbejdelsen af NM, selv om de erkender, at noget sker. Jeg tænker ikke selv på, at Grundtvig nu får færdige meninger om alt, men på en opdagelse af livet og virkeligheden, der bringer alt i skred. Men det nye syn formuleres først, efterhånden som de konkrete spørgsmål melder sig. Selvopgøret i 1831-32 har imidlertid medført et nyt udgangspunkt. Jeg er P. Th. taknemmelig, fordi hans kritik har nødet mig til her at uddybe forskellen på I83 1 og I832-34 som endnu et vidnesbyrd om, at Grundtvigs livssyn kæntrer i løbet af en vinter. Tesen holder. 
holdet mellem fantasi, følelse og forstand), menneskeåndens frihed, skolen for livet, grundlaget for skolens oplysning (det folkelige på modersmålet), den kirkelige forvirring, sondringen mellem det »andet « liv og det nærværende (vendt mod den lutherske tradition, jfr. et udkast fra $1_{8} 86$, Bugge s. 275), sekulariseringen af det religiøse element (tro på guderne etc.) og adskillelsen mellem en borgerlig og menneskelig og en kirkelig omvendelse. Bugge kender udkastet, men springer over dets betydning i denne sammenhæng. Som P. Th. lader han sig forvirre af nogle sætninger i »Den Danske Stats-Kirke«, et skrift, der er utænkeligt uden den »borgerlige og menneskelige omvendelse $\ll$ i 1832 , men som har sin bestemte hensigt i en bestemt situation. Folkelivet skulle ikke heller i 1834 så lidt som i $18{ }_{3} 6$ være kristeligt (jfr. Bugge s. 276). Bugge har undladt at dokumentere den løse forbindelse mellem de tre årstal. At Grundtvig på grund af stænderforsamlingerne bliver slået af danskhedens og folkestemmens opstandelse i 1836 , er en af de mange følger af gennembruddet i i 832, som Grundtvig nu er blevet disponeret for at se. Det verdslige ords opstandelse har nu fået kød og blod, efter at han i 1832 havde fået øje for, at det levende ord var selve åndedrættet $\mathrm{i}$ historien. At det forstås sekulariseret, er ikke noget nyt i i 836 , kun at munden nu har besteget tronen, og Danmark nu har fået stemme. I I832 tænkte han på Nordens ånd. At kristendommen »ad en Omvej《 vil kunne gavne den danske natur, ligger i direkte forlængelse af dens indirekte, inspirerende betydning, den fik tildelt i 1834 . Og når Grundtvig nu slår fast, at kirketiden i borgerlig forstand er forbi, nu er det skoletid, har det sit udspring i indledningen til NM, hvor den kirkelige periodeinddeling er afløst af en inddeling i kulturepoker. Det afgørende er sket med »den sobre adskillelse mellem tro og anskuelse, som ... har holdt sit indtog i Grundtvigs tankeverden og er kommet for at blive« (Bugge s. 26o).

Adskillelsen mellem det menneskelige og det kristelige har selvfølgelig også her sin rod. P. Th. kalder udtrykket »adskillelse« »temmelig intetsigende« (s. 598), jfr. at både bodskristendommen og den profane kultur jo også skiller det menneskelige og det kristelige. Og det kan man jo godt sige, hvis man ikke lægger nogen vægt på Grundtvigs mening med ordene - som jeg dog ikke har lagt skjul på i bogen. Den fremkommer, når man tager hensyn til sammenhængen og parallelle steder. Hvordan skulle man ellers tolke? P. Th. anerkender, at jeg også har fundet vanskelige steder frem i det utrykte materiale, 
men om mine tolkninger siger han: de virker »efter mit skøn ikke overbevisende« (s. 597). Det dokumenteres ikke, men for at ordene ikke blot skal komme til at henstå med deres dunkle autoritative vægt, må jeg gå nærmere ind på den principielle forskel på vore arbejdsmåder. Spørgsmålet er simpelthen: hvorfor forsker vi?

For P. Th. er det et hovedsynspunkt, at Grundtvig ikke var konsekvent. Hans tankegang var »fyldt af modsigelser « (s. 598). Ja, dem har jeg også stødt på og har ligefrem støvsuget materialet for at få dem frem. Man kan så enten lade dem stå uformidlet og ligefrem deri finde et vidnesbyrd om, at Grundtvig var et levende menneske - for hvem er konsekvent?

Men når jeg nu har valgt det legitime emne at analysere Grundtvigs opgør med sig selv og spørge, om han efter sit store opgør holdt linien, så regner jeg med, at Grundtvig på anden måde end ved at være inkonsekvent var et levende menneske. Jeg spørger ham hele tiden: jamen, hvad mener du egentlig? Det spørger man måske ikke hvemsomhelst om, for der er jo blandt både levende og døde en del, hvis mening man ikke vil ofre år på at få opklaret. Men man spørger Grundtvig, fordi man her virkelig møder en udfordring: der var noget ganske bestemt, han mente og ville og også fik sagt. Og står man så over for selvmodsigelser, bliver man ikke stående her. Man spørger sig selv: jamen, hvor ligger vægten? Hvad er betonet, og hvad er ubetonet? Hvad løber med i farten, og hvor er det, han i virkeligheden vil hen? Hvad er hans hovedlinie, og hvor og hvorfor afviger han fra den? Der må være særlige grunde dertil. Undertiden måske ligefrem den - det er jo Grundtvig, der er tale om, at en manisk tankeflugt tager magten. Det er en historisk opgave at finde frem til den egentlige mening $\mathrm{i}$ et forfatterskab, ligesom man skylder det levende menneske, man står overfor, den respekt at spørge: hvor er det, du vil hen? Hvad er dit ærinde?

Hos P. Th. finder man en række eksempler anført på inkonsekvens hos Grundtvig, udover de allerede anførte en del henvisninger til citater hos mig, der skal vise, at det menneskelige bliver noget mere end en betingelse, en forudsætning for kristendom: »... det fører virkelig til kristendommen « (s. 597). Derudover er der et sted (fra V. U.s. 392 ), der dog er forkert gengivet. Iflg. P. Th. siger det, at »folket virkeligt på ny vil blive kristeligt, når præsterne bliver folkelige«. Der står imidlertid, at når præsterne bliver folkelige, »da følger deraf . . ., at folket, som har nogen tro, paany bliver kirkeligt «. Det er jo noget 
andet. I det hele taget kan man kun finde inkonsekvens hos Grundtvig de pågældende steder, hvis man opfatter dem lige så upræcist. Det menneskelige fører ikke til kristendom hos ham. Adskillelsen mellem menneskeligt og kristeligt er i denne henseende af luthersk art. Men desuden betyder den, at uden om det menneskelige - ingen kristendom. For det er menneskelivet, der frelses. Adskillelsen er udgangspunktet for, at der i kirken nu kan tales sandt om »den vidunderlige Sammenhæng «, der er mellem menneskelivet og kristendommen. Hele Grundtvigs kristne forkyndelse taler højt om, hvilken mening evangeliet på denne måde har fået for ham.

Ligesom adskillelsestanken, hvis fødsel sker i NM med sondringen mellem tro og anskuelse, er forudsætningen for Grundtvigs kristendomsopfattelse, hans kirkelige forkyndelse af den enhed mellem himmel og jord, som evangeliet betyder, er den også udgangspunktet for hans tale om vekselvirkning mellem det folkelige og det kristelige. Uden klar adskillelse ingen fri og levende vekselvirkning. Dette ord træder først i kraft efter 1832 .

På denne måde er denne tanke om adskillelse (som netop er en adskillelse for tanken, som Grundtvig siger, mens livet selv er en enhed) afgørende for at fatte Grundtvigs ærinde. P. Th. finder den ikke »særlig træffende « (s. 598). »Grundtvig vil på een gang hævde sammenhængen og skellet mellem det menneskelige og det kristelige«. Dette »på een gang « er for mig slet og ret tågetale. Hvis det skal være en ledetråd under læsningen af Grundtvig, fører det til den ene tvangstolkning efter den anden. Selve det enkelte steds mening og hensigt går tabt. Og der vil for alvor blive lejlighed til at fastslå, hvor inkonsekvent han dog er. Men P. Th. konkluderer da også i, at hele forholdet mellem de to »faktorer « er så spændingsfyldt og dialektisk, at det i grunden vedblev at være »et åbent spørgsmål« for ham. Hvis det skal betyde, at Grundtvig i den givne sammenhæng ikke vidste, hvad han skulde sige om det menneskelige og det kristelige, vil jeg sige et afgjort nej til P. Th.s påstand.

Grundtvig kommer til sin sag fra så mange sider, at han også kommer til at udtrykke sig på meget forskellig måde. Det er det levende ved ham, at han går ud fra livets skiftende situationer, ikke fra noget skema. Men hans tankegang går ikke i stykker. I periferien af den kan der være dunkelheder, men er det ikke respekt over for manden at søge at forstå dem ud fra hans hovedtanker i stedet for 
at blive stående ved at konstatere en inkonsekvens eller hævde, at Grundtvig ikke er kommet til nogen virkelig klarhed?

Der er forskel på P. Th.s og min tilgang til historien, in casu Grundtvig. Den kan belyses på anden måde, nemlig ud fra vor forskellige behandling af forholdet mellem Grundtvig og grundtvigianerne, som jeg dog kun strejfer. Jeg betoner modsætningen, han ligheden. Det svarer til, at jeg gennem årstallet ${ }_{1} 8_{32}$ søger ind til det springende punkt under Grundtvigs selvopgør, mens han søger at udviske det års betydning ved at påpege de tidligere erkendelser og de senere opdagelser, foruden afvigelserne fra klarheden af 1832 . Især fremhæves hans vedvarende afhængighed af bodskristendommen. Det vil altså sige, at han stadig søger kontinuiteten, mens jeg søger det nye, og det vil sige det udfordrende, mandens særlige ærinde. Den historiske Grundtvig er for P. Th. det fænomen, der glider på plads mellem de andre kirkehistoriske fænomener i historiens forløb, et sammensat fænomen, hvis sammensathed den historiske forskningsiflg. P. Th. må kræve kortlagt. Jeg derimod søger hjertepunktet, manden selv $\mathrm{i}$ hans »Einmaligkeit«. Det mener jeg den historiske forskning kræver.

Men den opgave, P. Th. ser for sig, er for let. Man kan altid finde ligheder. Det svære er at formulere de rette distinktioner, men det er også det mest givende, fordi det er det mest udfordrende. Man kan sagtens tegne et billede af Grundtvig som grundtvigianismens lærefader og ligesådan af ham som pietist eller som barn af det nittende århundrede. Det kan være nyttigt til påmindelse om, at man ikke kan lære noget af historien ved blot af kalkere den af, imitere den. Men det er vel en »uvidenskabelig « anmærkning, for forskningen skal jo blot være forskning! Den skal blot beskrive.

Før jeg i fortsættelse heraf trækker linierne op til slut, må jeg svare på den anklage, at min bog giver indtryk af, at Grundtvigs kirkelige virksomhed efter I $83^{2}$ kun spiller »en sekundær rolle« (s. 599). Hvis det var rigtigt, var mit Grundtvigbillede virkelig blevet fortegnet, altså uhistorisk. Nu er mit emne ganske vist hans selvopgør, og jeg har ikke villet give et systematisk billede af hans kristendoms- eller kirkesyn, så lidt som af hans folkelige syn eller filosofi. Hvad de 3000 prædikener og de I 500 salmer angår, kan de udfra mit synspunkt ikke kvantitativt komme forholdsmæssigt til orde - så lidt som de 9 bind poetiske skrifter. Men mit stofvalg svarer nogenlunde til forfatter- 
skabet efter $183^{2}$, som det er repræsenteret i Begtrups udvalg (som dog bl. a. mangler højskoleskrifterne og »Mands Minde«) og i Håndbog i Grundtvigs skrifter (Borup og Schrøder): her er de 250 af 800 sider hentet fra den kirkelige del af forfatterskabet, som fylder mindre end man tror.

P. Th. forlanger ikke, at jeg skal forstå Grundtvig ud fra hans eget syn på betydningen af fundet i i 825 . Han erkender selv, at opdagelsen af menneskelivet ikke »uden videre« kan afledes af 1825 (s. $5^{85}$. Det er ikke rigtigt, at hans bodskristendom aldrig var vendt mod skaberværket - se f. eks. min tolkning af SB III s. $69 \mathrm{ff})$. Vor uenighed iøvrigt m.h.t. udviklingen 1825 til 1832 og forholdet mellem det levende ord og kirkeordet (det lille Guds ord, som trods P. Th. ikke forekommer i ægte grundtvigsk betydning før 1832) må jeg lade ligge med henblik på min senere redegørelse. Men det afgørende er da også hans påstand om, at min »aktualiserende, eksistensteologiske fortolkning af Grundtvigs forkyndelse og teologi fortegner væsentlige sider af hans kirkelige syn, som ikke let lader sig »afmytologisere«: hans konkrete opfattelse af kirken som et særligt »kendeligt« folk, hans forståelse af kristenlivet som et virkeligt, fremvoksende liv, der fødes ved dåben og næres ved nadveren, hans frelseshistoriske og eskatologiske tankegang m. m. Jeg anerkender det værdifulde $\mathrm{i}$ forsøget på at oversætte Grundtvigs begreber til moderne tankegang; men der er forskelle, som ikke må overses; og en sådan oversættelse forudsætter en klar opfattelse af begrebernes betydning i deres oprindelige sammenhæng, kort sagt en erkendelse af den historiske afstand. Det er forståeligt og fuldt legitimt, at Thaning søger at fremdrage »den levende Grundtvig«, men en afhandling af denne art må dog i første række tilstræbe at give et korrekt billede af »den historiske Grundtvig« (s. 6oo). - Hermed slutter P. Th.s kritik.

$\mathrm{Nu}$ har jeg i det foregående vist, hvordan P. Th. har misforstået min brug af ordet sekularisering. Det er netop ikke brugt ud fra en moderne tankegang, men er et hjælpeord, der skal tolke Grundtvigs egen adskillelse af tingene. Den historiske afstand er netop fastholdt, mens $\mathrm{P}$. Th. afviser tolkningen ud fra sin moderne, oven i købet »sekularistiske« brug af ordet. På samme måde forholder det sig med de meget få gange, jeg har brugt ordet »eksistensteologisk « - netop i anførselstegn: det får sit indhold udelukkende fra Grundtvig selv. Han forstår kun teologien på baggrund af en menneskeopfattelse, en konkret forståelse af den menneskelige eksistens - og uden tvivl en anden, 
end den moderne eksistensfilosofi tænker ud fra. Men ingen kan dog tage patent på ordet eksistens, som jo kun betyder tilværelse. Den brod er der i min brug af ordet i forbindelse med Grundtvig. Deraf anførselstegnene. Endelig kan der være tale om min brug af ordet »forudforståelse«. Men jeg kan da ikke gøre for, at Grundtvig har opfundet det begreb roo år før andre! Om ikke selve det ord, så dog ordet »forudfølelse«. Sagen er den samme - men ikke den samme som hos Bultmann. Intet er hentet fra ham til brug for tolkningen.

Grundtvigs aktualitet forstår jeg altså ikke ud fra en eller anden lighed med moderne tankegang. Derimod ud fra hans modsætning til den. For at kunne klare sig den, må man netop fastholde »den historiske afstand «. Ellers kommer udfordringen jo ikke frem. Det er nødvendigt at opfatte »begrebernes betydning i deres oprindelige sammenhæng « - men hvad andet har jeg søgt at gøre, når jeg har forstået hans teologi ud fra Irenæus, hans filosofisk-religiøse udviklingsog menneskesyn ud fra Schelling og hans historiesyn ud fra bibelen, ikke mindst Johannes åbenbaring! Men den afgørende hjælp til at forstå, hvad det er Grundtvig mener, er at få øje på hans opgør med sig selv og sin fortid. Det er her, Irenæus træder til med sit opgør med gnosticismen og Schelling med opgøret med det 18 . århundredes statiske tankegang.

Har jeg »oversat« eller »afmytologiseret«? Nej, jeg har netop søgt. at forstå Grundtvig ud fra hans egen situation, ud fra hans begreber »i deres oprindelige sammenhæng «. Først herudfra kommer der mening i hans vækst- og udviklingstanker, hvis kærne altså intet har at gøre med det 19. årh.s udviklingsoptimisme. Det er ham selv, der taler om mytologi og myter i teologien, frigjort som han er fra bogstavbundethed, suveræn i forhold til brug af alskens billedsprog. Deraf også hans eget personlige forhold til den bibelske frelseshistorie og eskatologi. At hans syn på kirken som et »kiendeligt« folk tilspidses derhen, at den kun er kendelig på ordet - bekendelsen, forkyndelsen og lovsangen, har jeg vist, skyldes opgøret med Kierkegaard. Læst umiddelbart fornemmes hans tanker i høj grad som fremmede for os. »Der er forskelle, som ikke må overses«, slår P. Th. fast. Ja, det er vist og sandt. De er ikke lette at overse. Men hvordan bliver vort forhold til historien et levende forhold? Er det ikke kun, hvis man opfatter dens personer som levende mennesker i kamp med deres egne problemer og med den klarhed, der derigennem kom frem? Det er deres selvopgør, der taler. Men det taler først, når den historiske af- 
stand fastholdes og det for os fremmede får mening ved at forstås i historisk belysning og som udtryk for opgør.

»Et korrekt billede af den historiske Grundtvig « bliver ikke korrekt, hverken ved at (tilsyneladende) selvmodsigende udsagn placeres uformidlet ved siden af hinanden, eller ved at en ideologi eller en teologi udbredes med alle dens komponenter for vore øjne - med iagttagelse af statistisk ligevægt imellem dem. Heller ikke ved påvisning af arvegods: noget Luther, noget Irenæus, noget bodskristendom, noget gods fra det 19. årh. Jo mere skildringen får dette præg, jo mere ligegyldig er den. Og jo mere ukorrekt. Positivistisk historieskrivning fører ikke frem, når det gælder mennesker. Den får ikke fat i deres opgør med sig selv.

P. Th. anerkender legitimiteten af et forsøg på at fremdrage »den levende Grundtvig «, men stiller det i modsætning til det, der måtte have været min opgave i et arbejde »af denne art« (en disputats?). Her måtte man »i første række« give et korrekt billede af den historiske Grundtvig. Men hvis det virkelig er manden selv, der kommer til orde - gennem sit selvopgør, uden moderne indlægning, og hvis det viser sig, at hans ord så angår os (lad det komme an på en prøve!), så er den historiske Grundtvig den levende Grundvig (ligesom omvendt). Der er ingen rækkefølge ${ }^{3}$ ).

Kaj Thaning.

3. Følgendte forkortelser er anvendt:

Gr.st.: Grundtvigstudier.

NM: Nordens Mythologi 1832 .

SB III: $\quad$ Søndags-Bogen III 1831 .

U. S.: $\quad$ Udvalgte Skrifter v. H. Begstrup I-X.

Romertal: Udvalgte Skrifter v. H. Begstrup I-X.

V. U.: $\quad$ Værker i udvalg v. Georg Christensen og Hal Koch.

M. f.: Kaj Thaning: Menneske først -. 